\title{
Co-housing Professionals as 'Middle-Agents': Perspectives from the UK, USA and the Netherlands
}

MELISSA FERNANDEZ ARRIGOITIA and LIDEWIJ TUMMERS

Keywords: co-housing; professionals; consultants; institutionalisation; middle agents

\begin{abstract}
This article explores the role of co-housing professionals in three countries (the United Kingdom, the Netherlands and the United States) where the relevance of this form of collaborative dwelling has grown. Co-housing initiators everywhere have to hire external technical consultants like technical financial and legal advisers and traditional project managers. These 'experts' or 'professionals' may, however, be insufficiently equipped to deal with the development particularities of co-housing which require the ability to move between and translate knowledge(s) of different kinds. In response to this reality, a new cadre of co-housing specialists such as groupfacilitators, process-management and legal coop-specialists is emerging, but the specificity and implications of their roles has gone largely unstudied. Drawing on interviews and fieldwork across the three countries, we explore the roles and dynamics, as well as the paradoxes faced by this varied professional sector. We argue that as 'middle agents' that must negotiate their way between niche and mainstream housing landscapes, co-housing professionalisation is taking place in a way that can potentially transform both grassroots and mainstream housing provision. Based on this, the conclusions recommend a shift in higher education and specialist training.
\end{abstract}




\section{Introduction}

Across Europe, there is a surge in citizen-led experimentation with old and new forms of sharing economies, autonomous and ecological forms of living and more affordable housing models. This growing social and environmental consciousness can be partially linked to the post-2008 global crisis context (Mullins and Moore, 2018), when speculative house and land prices grew and job insecurity increased for previously un-affected middle-class groups. It is also a response to what is considered to be a woefully slow implementation of crucial sustainability policies, particularly in the housing construction sector (Stevenson, Barborska-Narozny and Chatterton, 2016). Co-housing initiatives, in particular, have been re-emerging as an alternative social and environmental offer to the mainstream market in this context.

In a recent Special Issue on self-organised and civil society participation in housing provision in ten countries (Mullins and Moore 2018, p. 9), the editors argue that the evidence gathered demonstrates a '... need for skilled, professional input to support organisational growth and sustainability'. Before the call fort this special BE issue, the range of roles played by individual professionals working in co-housing from across a variety of occupations, and the issues they have to contend with in their working practices, remained understudied ${ }^{1}$. This article ${ }^{2}$ begins to address that gap by exploring the roles played by co-housing professionals in the Netherlands, the UK and the USA. It identifies some of the typical and emerging occupations engaged with the co-housing sector and discusses key issues faced by these professionals in their working practice. In comparing findings across these countries, it argues that there are identifiable trends in the ways professionals from certain occupations are finding themselves involved in the sector. Some of these trajectories can be understood as part of a wider process of co-housing professionalisation; i.e., a process by which the sector is becoming more self-sufficient and professionally inserted in mainstream processes of mainstream housing production. Our contribution seeks to shed light into the way professionals work in this community-driven sector and the particular issues they contend with. Conceptually, it develops a 'middle-agent' approach (Janda and Parag, 2013) to professionals and explores the implications of being caught in a kind 
of paradox between the bottom-up, democratising values of individual co-housing initiatives, and the institutionalisation of expert knowledge and professional practices.

In what follows, and after a brief description of our methods, we first clarify what we mean by key terms in this article: co-housing, professionals and professionalisation. The article then provides a brief background to the co-housing model in each of the countries, with a focus on the support offered to professionals. This is followed by our conceptual framework on 'middle agents', leading to a discussion of our findings regarding the issues and risks associated to becoming professional. We argue that all co-housing professionals and consultants - and the collaborative paradigms which they operate within - must contend with a paradoxical position between grassroots and mainstream housing provision., which also enables them to potentially transform those systems. Based on these findings, our conclusions make the case for a shift in higher education and specialist training.

\section{Methods}

Two main sources of data are drawn upon to support the analysis. First, material from sixteen in-depth interviews (see Table 1) carried out for a funded research project on the topic of professionalisation between August and October 2015 in USA, UK and Netherlands ${ }^{3}$. The sample countries were selected to reflect places where co-housing is fairly developed or re-emerging, making them productive arenas from where to investigate the various roles professionals play in that growth or resurgence. Thinking comparatively across the themes emerging from the countries helped to identify patterns and divergences in professional roles and trajectories, and how institutional support has been variously employed, with distinct effects. This approach builds on work form comparative urban (Robinson, 2002; Fainstein, 1994; Sassen, 1992) and cross-national housing studies (Jarvis, 2015; Moore and McKee, 2012; Tummers, 2015a) that look beyond single-country case studies in order to generalise or extrapolate findings based on similarities and variations.

\section{Insert Table 1 around here}

Further comparative insights are drawn from more than seven years of each authors' fieldwork and first-hand participant observation on different aspects of co-housing 
development in the UK, the Netherlands, Germany, Austria and France (see: Fernández Arrigoitia, West and Scanlon 2018; Fernández Arrigoitia and Scanlon, 2018; 2015; Tummers, 2015a; 2015b). These in-depth, longitudinal projects have given each author unique access to professional co-housing practices, and to larger networks of national and international support. The fieldwork supports the analysis of some of the professional practices and processes that our interviewees spoke about. While we do not claim the interviewee sample to be representative of the entire professional spectrum operating within each country's co-housing sector, those we spoke to do cover a wide range of professional occupations and approaches and have ample experience in co-housing developments. Their self-reported experiences coupled with our long-term involvement in the field and repeated discussion of the findings in the co-housing researchers' network, which provoked recognition rather than counter-evidence for the dynamics outlined, allows us to offer a first exploratory analysis of professional roles, dynamics and paradoxes in co-housing.

\section{Co-housing models and their professionals}

\section{Contemporary co-housing}

Contemporary co-housing has emerged as a housing form that combines private spaces with collective facilities to enhance social activities and facilitate interaction between neighbours. Its typologies have been variously translated to countries as varied as Australia, Poland, Japan and the UK, with physical layouts ranging from small, low-rise clustered housing around a central courtyard to retrofitted country houses or high-rise buildings with communal facilities. Projects are typically, although not exclusively, co-designed between residents and architects to reduce caruse, include individual private spaces (owned or rented) as well as a shared environment (see: Wohnbund, 2015 [ed.]; Tummers, 2015a [ed.]; Krofkors, 2012 [ed.]; Fromm, 2000 [ed.]). It can be created by a group of assembled individuals who act as developers (this is broadly termed, community-led), or it can be generated and led by other kinds of 'mid-way' developers like housing associations, corporations or non-profit organisations (known as collaborative housing). Senior-specific (over 50s) cohousing schemes are also becoming popular as a non-institutional form of 
communal ageing in place that can help prevent dependence on family members or intermediate options such as 'assisted living' or 'extra-care'; and is expected to enhance quality of life while reducing public costs (Andresen and Runge, 2002; Choi, 2004; Brenton, 2013; Chan and Ellen, 2016; Glass, 2012; Labit, 2015).

As such, co-housing is a plural phenomenon and the boundaries between what constitutes one form or another can be blurry. The focus of the research that informs this article is community-led co-housing, where residents are at the core of the development process, and the term 'co-housing' will be used henceforth to denote this specific type.

\section{Engagement with professionals}

To initiate a co-housing project anywhere, groups have to engage with the risks and issues common to housing development, such as land availability and cost, choice of sites, as well as complex planning and building procedures. With little development experience co-housing groups can lack the social, technical and financial expertise required to articulate needs, obtain planning permission and bring projects to fruition within an otherwise mainstream setting. Within a particular city or municipality groups may struggle to be recognised by established housing institutions. Planning and housing institutions, for example, typically consider future residents as consumers or beneficiaries, rather than co-producers or experts (Tummers, 2015a). Moreover, groups often challenge the value system that traditional development partners (e.g., architects, housing associations and mortgage lenders) operate on, who in turn may misunderstand fundamental values of the initiative ((Tummers, 2015a).

Co-housing initiators address these knowledge gaps and practical impasses in a number of ways. A common one is to hire external technical consultants, including:

- financial advisers (for revenue capital, forecasting expenditure and costs);

- lawyers (for legal guidance on property, tax, contracting and governance);

- built environment experts (architects or landscape people for design and survey and planning materials). Most groups rely on architects, especially firms specialised in participative design and/or sustainable building, for technical advice; 
- housing enablers (policy, regeneration, health and social care representatives, and other advocacy processionals);

- construction experts (structural, civil or landscape engineering; planners); and

- 'secondary level' actors in the financial and legal fronts like conveyancers and estate or land agents as well as other training professionals offering educational support around governance or organisational development.

The above can all be understood as 'traditional' professionals in the housing development field. So, how far can co-housing be understood to constitute a new field of expertise? Surely, structural engineers can construct safe premises even if the client is a group of households united under a cooperative or as other legal structure. What, exactly, is different about the type of professionals that are needed for co-housing, and purportedly not available in the mainstream? The overview of co-housing professional and consulting typologies and titles outlined in Table 2 reveals that even though there are many traditional professions involved in the sector, additional skills and different knowledge are needed. This is reflected in the variety of new professional titles (e.g., building coach) and descriptions emerging alongside traditional housing professions.

\section{Insert Table 2 around here}

The author's fieldwork experience and interviewee responses suggest that housing professionals may be insufficiently sensitive to community housing needs and 'lay' knowledge(s). We found a type of co-housing specialist emerging, partially as a response to this professional knowledge impasse, with their expertise often arising by developing their own co-housing projects. Incorporating mainstream and group concerns as part of a working practice, however, puts additional demands on the creativity of those professionals, who will need to find ways of not just enabling the group's success, but of facilitating internal critiques regarding power and inequality. This approach requires a different attitude from some of the hired professionals who may be less accustomed to operating outside a private market-led logic.

A profession is typically considered to be (waged) occupational work that requires advanced or specialist knowledge that is imparted impartially (Evetts, 2003). 
Professionalisation, in turn, has been framed as an ideological construct that takes place in relation to the emergence of occupations; as,

'...a process to pursue, develop and maintain the closure of the occupational group in order to maintain practitioners own occupational self-interests in terms of their salary, status and power as well as the monopoly protection of the occupational jurisdiction...' (Evetts, 2011, pp. 6-7)

Our framing of co-housing professionals as middle-agents puts into question the extent to which objectivity and distance are necessary or even desirable in the pursuit of co-housing development success. This, in turn, raises the question in how far professionals can be expected to take a position, or even responsibility for how groups can perpetuate exclusionary mechanisms. These tensions are discussed after we situate the broad evolution of co-housing professional support in each of the case countries.

\section{Co-housing professional support per country ${ }^{4}$}

The housing landscapes of the countries analysed here have different approaches to co-housing as a niche market. In the Netherlands and the UK, for example, Housing Associations (HAs) have acted to differing degrees as key development partnersbringing their existing professional infrastructure to the group. But their involvement can be complicated due to the wider fiscal and political environments that determine the possibility or scope of their engagement. Financial crises contexts, in both of these countries, led to a reduction of HA's share of national grant budgets (Hickman et al., 2018) which has affected their ability to invest in co-housing 'experiments'. On rare occasions, a for-profit developer (individual or corporation) can become involved, a practice that is most common in the USA.

\section{Netherlands}

Civil initiatives for customized collective and environmental projects began to emerge more strongly in the Netherlands during the 1980s as a response to the changing demographic and sustainability needs that traditional housing design and development 
was ill-equipped to handle (Qu and Hasselaar, 2011). Still, the Netherlands has the lowest percentage of overall self-development housing in Europe due to the dominance of developer-led housing market and a state-led planning regime of production $^{5}$.

The Dutch co-housing model, called Centraal Wonen (CW), of which there are around 800 in the country, typically offers social rental apartments. This obliges projects to collaborate with officially licensed housing corporations. Initiatives for senior co-housing, of which there are around 150, operate on the same basis and have become part of the social housing sector, offering diverse degrees of medical and household services. The Co-housing Federation (Vereniging Gemeenschappelijk Wonen) supports co-housing projects with knowledge exchange, but no longer performs the consultancy work it used to during the 1980s.

Resident-led projects received a new impulse in 2000 through the introduction of a national policy that sought to stimulate home-ownership through self-development. While policy implementation is based on individual self-build plots, some local authorities encourage the German Baugruppen (group build) variety through partnerships between housing institutes and residents' groups, called Collective Private Commissioning or CPOs in the Netherlands (Tummers, 2015b). Following the southern German examples of Tübingen and Freiburg, DIY-housing has even become the basis for urban expansion, notably in the new-town Almere (Bresson and Tummers, 2014). In 2014, the Ministry of Economic affairs created an Expert Team to assist local authorities in setting up infrastructure to promote self-building. Despite these changes and the creation of new planning instruments (such as handbooks and subsidies) as well as government agencies to mediate between self-builders and institutional partners, the percentage of annual 'self-build' production, both individual and CPO, remains below 15\% (Platform31, 2017).

\section{The United States}

Co-housing is the most typical form of intentional community in the USA (the umbrella term for collaborative housing in that country, which includes co-ops, communes, eco-villages). The first co-housing project was built in 1991 by a pioneer couple in the style of the established Danish projects ${ }^{6}$ (Killock, 2014). As of 2019, the Cohousing Association of the USA reported 165 established communities in 36 states, 
and another 140 in stages of formation. Zoning regulations have been noted as a particular obstacle to the diffusion of the sector as these tend to limit the possibility of specific co-housing material features to be approved (Boyer, 2014).

There is evidence that the movement as a whole has been moving towards more diverse environmental values and practices (Kirby, 2003; Sanguinetti, 2014), that its appeal is much wider than what its existing population demographics would suggest (Boyer and Leland, 2018). Also, broader trends in the professionalisation of sustainable development work (Holden 2008) has led, in some cities, to the hiring of professional planners to implement climate action and mitigation plans - a move which can complement co-housing goals and development plans (Boyer, 2014, p. 458).

Moreover, despite professionals like architects, financiers, builders, and local planning officials having little experience collaborating with groups as a client (Boyer, 2014), it is not uncommon for community-led projects to shift to a 'developer-led' model over time, as the need for financial backing and professional expertise becomes more apparent to its lay members (Sullivan, 2016, p. 552). Over time, members with capital or particular housing and urban development expertise can become the professional developers making decisions in the name of the group (ibid.).

A highly developed system of social consultancy coupled with architecture practice appears to be in place here. One architect interviewee noted that their practice can teach compassionate communication mechanisms to the group and train other local architects to cope with the facilitation process to avoid burnout if the process becomes too long. She did not see this as 'training the competition', but rather as contributing to 'growing the pie'. Indeed, all USA interviewees pointed out something 'special' or a key skill, which they had learned or adapted from other professionals they held in high esteem. But according to some development consultants interviewed, there is still rare professional understanding or capacity to bring sales, recruitment and group process together - a task that, they believe, savvy consultants with solid social and marketing skills (not real estate developers) could take on. 


\section{The UK}

In the UK, co-housing is a young but growing trend that began at the end of the 1990s in East Sussex (Ruiu, 2017). The sector now boasts nineteen built communities and more than sixty-five groups in development ${ }^{7}$. Senior co-housing is becoming particularly popular (Brenton, 2013; Dittmar et al., 2016), with its first new-build scheme - the Older Women's Cohousing Group (or, OWCH) - inaugurated on December 2016 . LILAC (Low Impact Living Affordable Community) opened its doors in 2014 and is held up as a key example of sustainable intergenerational living in social, financial and ecological respects (Woodin et al., 2010; Chatterton, 2015). Through extensive outreach and publicity, these flagship projects have generated a surge of new demand in the co-housing model.

There are now regional and national mechanisms in place to help co-housing develop, including the Homes for Londoners Community Housing Hub, launched by the Greater London Authority (GLA) in 2017 as a free public consultancy service that advises groups on how to access land and funding, as well as offering technical and informational support. Most recently, the National Government has launched a Community Housing Fund ( $£ 163$ million) to support community-led housing groups in their delivery of affordable homes. Local authorities can also bid for capital funding for small-scale infrastructure projects to unlock sites that the community can subsequently develop for housing (Homes England, 2018). In 2019, Community Led Homes was launched as a project between Co-operative Housing, Locality, National CLT Network and the UK Cohousing Network to provide advice and funding and gather resources on the sector into one place.

\section{The co-housing professional as middle-agent}

\section{A range of professional roles}

In the USA, the UK and the Netherlands, as co-housing has become more established, architects, project management firms and some housing association personnel are increasingly self-identifying as experts (or supporters) of the field. Many of these professionals call themselves consultants and help co-housing groups develop different aspects of their process: from design, development and project management, to group facilitation and marketing advice, and they can combine more than one of 
these roles at once. Some professionals work directly with municipalities to open up planning opportunities for co-housing, for example in the new town Almere or urban renewal in Rotterdam. A consultant from one of these new self-build consultancy firms explained that 'the pilot stage' was over and Dutch municipalities were now more familiar and comfortable with the projects, treating private clients 'like corporations or real estate developers'. This suggests that a professional threshold is imagined as having been reached once the government (municipalities) treats groups in the same way as they do a private, for profit entity.

Four out of the five UK professionals had previously worked in some capacity with local authorities, which made them aware of council and planning issues (e.g., landuse conversion restrictions, land and site scarcity). These histories are important because in helping to develop groups (their own or others') these interviewees had also gained knowledge about the inner workings of municipalities, legislation, building regulations and ministries, which they could then pass along to others as more formal consultants. This unique perspective allowed them to steer and communicate with different kinds of stakeholders. Still, in the UK, one professional who self-identified as working in/with the niche area of co-housing said that while,

'there are enough people with overlapping interests that are getting traction [in co-housing], the grittier area of consulting is still quite new'.

Indeed, at the time of the research, there was only one company that was labelling itself specifically in co-housing development support, and they used their experience to expand to self-build and custom-build groups. Experts like them are more likely to now be working under different affordable or cooperative housing sectors such as 'development trusts', 'empty homes' 'CLTs' or 'cooperatives'.

Architects often play an important role facilitating the participatory design process emblematic to co-housing development. Interviewed architects in the USA and the Netherlands drew upon these collaborative design experiences to become 'group dynamic' experts. Also called 'social facilitators', the additional professional skills required concern communication and decision-making. As one Dutch respondent explained, the social process must involve social design (in terms of rules, decision making processes, etc.), a kind of 're-socialisation', while the architecture must also respond to socially orientated questions. Two social facilitators in this study from the 
UK and the Netherlands, for example, were academics that turned their theoretical knowledge about communities into practice: one has lived in co-housing since the 1970s and the other was a member of a developing scheme. Others, like two of the American interviewees, have strong environmental and ecologically oriented design backgrounds that led them to work with co-housing in the first place. Seeking out 'sustainability' experts within this field is not uncommon given that co-housing sometimes emerges out of a desire for more sustainable forms of housing, (Boyer, 2014; Jamison 2001). In the Netherlands, while the CW movement registers social consultants on their web site, the network members spoken to suggest this is still a 'totally underdeveloped' area of the professional sub-sector 'because it is the architecture and the legal [that] everybody understands...' . Along the same line, a UK interviewee felt that the more general social facilitators (versus specialists like architects) often have very little experience of enabling community-led housing and can end up leading groups down wrong path or missing critical spots.

In the US, the Netherlands and the UK, some architects have also expanded their roles to that of initiators, developers, moderators and project managers. In the Netherlands, it was the post-2008 crisis context that led many out-of-work architects to begin codeveloping projects. In the UK, a number of firms around the country have been accompanying groups in their co-design and development process. One USA interviewee noted that there is also a problematic, ethical conflict of interest when individual for-profit developers who happen to be architects act in both roles, as they can then hold an undue amount of power and influence over the group. This dual role is not uncommon in the Netherlands and, increasingly, in the UK.

Table 2 also shows another important emerging type of co-housing professional to be the 'building coach'. This role is tantamount to a 'project manager' for larger building projects with so-called professional or public clients. Responsibilities for this coach may include:

- Pro forma development

- Coordination/management of titling process

- Management of design, pre-construction and construction phases

- Liaising with government agencies

- Owner's representation during construction 
- Complex entitlement process on highly impacted site

- Coordination with multiple governmental agencies

- Establishment of design parameters, budget and financial feasibility

The extensive array of 'building coach' responsibilities can make their work essential for the practical success of a scheme's material delivery. And, like social facilitators, this role may be taken on by architects when they are acting as lead consultant to a group or as a project initiator.

\section{The significance of networks}

Strong individuals, or 'socially skilled actors' are key to co-housing projects' success, nonetheless, they do not operate as 'solitary heroes' but rely on knowledge sharing through networks. Both activists and professionals in the UK and the USA were strongly aware of the need to network and lobby as a way to move the model forward. They used national organisations (see Textbox 1) towards those ends. Most of the UK respondents also noted that there is a need for the co-housing professional landscape to connect more strategically with leaders in local authorities because a champion within an enabling council can bring in crucial capital revenue grant funding or help with planning conditions (see also Jarvis, Scanlon and Fernández Arrigoitia, 2016). In the USA where co-housing (like mainstream housing) tends to be racially homogeneous and socially exclusive (Williams 2005), professional interviewees in this research felt that the network was at a highly developed place from where to now address the problems of affordability and accessibility in the sector. Amongst other things, two interviewees hoped the network could start thinking about how cohousing could be more inclusive and provide some form of permanent affordability so as to avoid speculation and expand accessibility ${ }^{8}$. In this sense, 'professionalisation' is stronger there than, for example, in the Netherlands or the UK where the networks are strong advocates for the sector and connect groups to relevant development information but do less professional capacity-building. 


\section{Textbox 1: National cohousing networks}

The Dutch Cohousing Association, Vereniging Gemeenschappelijk Wonen (Community living association), has a membership of around 60 intergenerational communities, hosts an annual open day, and counts with about 800 co-housing projects. The Dutch Senior Cohousing association (LVGO) has about 150 communities organised within the National Association of Senior Communal Living. There is also a Dutch Federation of shared/intentional housing (FGW) that operates on a voluntary basis to share its experience and offer advice and support to existing residential communities. A wider range of alternative housing forms is connected through the network 'Anders wonen Anders leven' (Alternative housing, Alternative living).

The Cohousing Association of the United States has an online portal that serves as a 'go-to' space of 'how-to' documents for would-be groups, provides a database with contact information for the distinct kinds of professionals that may be needed at one stage or another of development and allows visitors to filter according to 'finding', 'creating' or 'living in' cohousing. The web of the Fellowship for Intentional Community, a non-profit dedicated to promoting cooperative forms of living, also hosts vast amounts of co-housing specific professional directories, resources and search engines.

The UK Cohousing Network and sister UK Cohousing Trust (its charitable arm) are actively working to support better integration of individuals with professional capabilities in the range of sector-specific projects and activities as a way of consolidating this growing housing subsector. New academic projects and multi-stakeholder collaborations are also emerging to support and promote community-led housing across the country.

\section{Framing the 'middle agent' position}

Whatever the role, working with co-housing as a collective client involves understanding group dynamics as well as the longer timings involved in consensus decision-making and overall project timeframes, as each of these has important implications. It also requires factoring in the time needed to 'translate' information and reconcile different design criteria between traditional and non-traditional regimes of practice (e.g., a non-traditional architect and a traditional contractor) (Boyer, 2014). Such time differences need to be factored into professional fee structures, but as discussed in later sections, this can appear excessive to groups and lead to a nonhiring situation. When hired, the longer and sometimes indefinite periods of development can contribute to the professional experiencing a decline in energies or burning out. This temporality can also become a risk from a financial point of view (Scanlon and Fernández, 2015), as professionals may be dismissed when a group runs out of money or needs to reprioritise goals in the case of unexpected delays.

Moreover, as Sullivan (2016, p.554) described, in the context of a developer (member)-led co-housing project in Texas, USA: 
'Although the goal of consensus is to open up all decisions for community critique and input, the time this would take translated into dollars and cents for developers who needed to keep construction on track by limiting community feedback.'

This highlights the way in which a professional's grasp of the traditional development relationship between time and money - and the need for efficiency-can lead to bypassing a co-housing group's consensus process. Here, being the 'middle agent' requires that the hired or appointed expert make, or at least influence, certain decisions for the group. In terms of the expertise this requires, the technical skills a 'traditional' professional brings to a group will not differ from those they would bring to a traditional development context. But the people skills needed to be effective with these groups and generate 'compliance and acquiescence' (Sullivan, p.545), do.

In the Netherlands, for example, representatives from the larger HA's who have supported co-housing work find that standardised processes or communication styles for dealing with traditional 'clients' do not readily coexist with co-housing groups as active participants in the process. In the UK, similar situations between HAs and their group clients has led on some occasions to partnership breakdowns and the end of a development (Fernández Arrigoitia and Scanlon, 2018). In most cases, what is needed is a change of attitude so as to shift the manner of applying existing professional knowledge.

We therefore identify two principal, interrelated issues that professionals taking up new co-housing projects are facing: first, we see co-housing professionals as having to act as 'middle agents' between residents' vision and the requirements of the house planning and building system. According to Janda and Parag (2013: 42) in their exploration of the (potential) role of professionals in the context of energy transition for residential environments, professionals are the middle agents between political contexts and the physical reality of a building. Altmann $(2015 ; 2016)$ and others (Bajracharya and Khan, 2010; Blandy and Lister, 2006) speak in a similar manner about the 'mediating force' of strata managers in multi-owner property (or condominiums) in Australia who provide the 'glue' linking individual owners to each other, while advising them on decision-making based on their specialist knowledge of wider institutional property frameworks. In the US, where powerful group members 
often become development experts, Sullivan (p.544) describes this distinguishing feature as an ability to 'access, digest, and disseminate technical information'. And in Vienna, Lang and Stoeger (2018, p.50) speak about influential professionals like architects and project managers as 'socially skilled actors' who,

'...can perceive and also seize opportunities in constraining policy environments... can induce a culture of cooperation for developing collaborative housing in the local and regional policy environment.. and effectively influenced the local institutional framework in Vienna through knowledge transfer as well as lobbying and networking practice.'

In our research, professionals that work with co-housing groups often indicated a condition 'between worlds'. They must respond not just to a groups' desire for working against the grain of traditional housing mores, but also to the established codes of conduct issued by professional institutions that work to secure a sector's boundaries (Hughes and Huges, 2013).

Janda and Parag (2013) further argue that there are established, self-defined 'jurisdictions' in what they call a system of professions. In other words, established professions such as engineering, urban planning and architecture are subject to strict codes of conduct and regulations generated through 'professional' associations. This works as a kind of circular self-sustaining system that, in the planning of co-housing as an alternative and autonomous form of production, could be limiting and counterproductive. An architect bound by a professional licence may not be able to deliver an experimental off-the-grid DIY technology requested by a group. But they can ensure that whatever gets designed is up to regulatory standards. And, while this can be understood as a kind of constraining 'middle-agent' circumstance for the professional, it is also, we argue, potentially transformative. When groups make particular demands like low-impact housing through some mode of participative decision-making, for instance, the professional imperative for making the group's need a reality, can in turn help push the boundaries of typical housing standards towards, in this case, more sustainable principles.

\section{Discussion: negotiating the middle agent position}


The specificity of this middle-agent position is conceptualised here both in terms of its 'between world' status and its potentiality to influence the mainstream market. Below we discuss the implications of this position, grouping the issues identified in two main themes: negotiating between personal and professional identities, and demarcating specific professional jurisdictions.

\section{The professional value of personal experience}

Interviewees, particularly those form the USA and the Netherlands, felt that their most useful contribution as professionals came from their experience of having set up and run their own co-housing communities. In the Dutch context, self-defined cohousing professionals (architects and social facilitators in particular, but also building consultants) were some of the early 1970s and 80s pioneers of co-housing. Their interest in co-housing or 'co-housing-like' developments generally stemmed from anti-authoritarian visions and alternatives to mainstream housing for traditional nuclear households. In the Netherlands, personal experience also brought forth the first generation of collaborative housing consultants, which are now established firms ${ }^{9}$. These recognised companies offer expert advice on group dynamics and decision-making, as well as financial and legal models and project management.

The facilitation skills learnt during their communities' development and their everyday experiences were felt to contribute a form of lived, embodied knowledge that cannot be entirely gained through formal training. Specifically, those respondents that lived in co-housing at the time of interview felt that their residential status granted them greater credibility. Their commitment to co-housing, evidenced through their own resident status and involvement in networks, was seen as an informal qualification alongside other types of formal or specialised training.

Mary, for example, noted that 'I understand every aspect, and believe in what they do.' She uses her +25 years of experience living in USA co-housing, as well as multiple professional engagements with the sector, to advise groups on a range of issues. She plays an important role in talking directly to banks, setting up investment structures, helping to get group members mortgages, advising on legal aspects and regulations - aspects, she said, groups can be rather oblivious to. Another interviewee had moved from being a volunteer community organiser, to being a paid marketing 
and outreach consultant (paid by a for-profit developer, to find groups and educate them), to becoming a developer and-due to both the financial crisis and personal circumstances - returning to her consultancy role. Both said their status as co-housing residents gave them their own space in which to be passionate about their co-housing community, which could help serve others better. This argument, then, was also crucially - about being perceived by their clients as more objective professionals. A Dutch architect similarly favoured hiring externals, arguing that hiring internally overlaid all kinds of complications to an already stressful development process. She felt that the latter practice can lead to an abuse of their specialist knowledge and group's trust, making the whole process lack transparency.

The question of objectivity (i.e., disinterested, unbiased and free from power plays) is key to how professionals are understood and valued. External professionals who are residents of other groups were perceived as having the knowledge yet emotional distance, 'able to be the bad 'fall-to' person, as one respondent said, if necessary. Out of their networks, they can also provide useful advice about who would be best to hire under individual group circumstances. What is evident from the interviews is that there are questions about how objective a co-housing consultant can truly be if they were acting/hired professionally by their own group to advise on technical or social matters (see also Sullivan 2016). In other words, while understanding the culture and drive of co-housing was seen as a valuable asset - a useful blurring of the lines between personal/technical expertise of co-housing process and culture-too much personal engagement was seen as a conflict of interest that may detract from providing a professional service, or the perceived ethical values of professionalism in this sector.

\section{Professional recognition and 'jurisdiction'}

For professionals, whether employed or freelance, money and time are key issues to contend with. Project managers, engineers and consultants charge a fee that depends on the service provided. Unless they have substantial amounts of capital to invest, professional donation of time and energy is not sustainable long-term. But groups often see professionals as an additional unnecessary cost and end up contracting for 
less hours or less activities to save money, at the same time that 'they'll spend endless hours discussing how hard it is to develop' (USA3). Groups may not realise that professional input can keep external fees down, for example, when they can bring in special prices given long-term relationships with other experts. The fact that the production of housing is generally an unknown process for initiating co-housing groups may also explain some of their misunderstandings about the relevance of hiring professionals. This lack of recognition of professional work as something to be remunerated, which Altmann (2015) also found in her study of strata managers, was also seen as problematic by some of the USA interviewees and highlights the relative novelty of co-housing. As one USA interviewee put it:

'When professionals come in, there's usually a little love fest, they all think they're mutually great and wonderful but dont understand how each other work and eat up each other's time. Then later, the architect realises they're losing money and cut back and the group doesn't understand what happened'.

Professionals we interviewed saw themselves, and not co-housers, as the ones that understand the niche co-housing business model, and emphasise the merits of streamlining processes and saving the group time. Groups, on the other hand, and as we have often observed, may see the time they dedicate to a project not as 'reinventing the wheel', or as a financial liability, but as an investment in their social outcomes- of value in and of itself. The reluctance to hire or pay externals demonstrates that professional involvement is not yet a fully integrated part of cohousing development.

When professionals are hired, selecting the right one can also be problematic. Group and development facilitators often have very little experience of enabling communityled housing or of actually understanding budgets. Those that do grasp these practicalities (say, an architect or project manager) do not necessarily understand this particular niche in real estate development or how to work with groups or consensus decision making. Informal arrangements and lack of experience present risks both for the architects and residents, such as unexpected delays, loss of investment, higher budgets or strained relationships (Scanlon and Fernández Arrigoitia, 2015).

Given this context, it is not surprising that building professional credibility was raised as an important factor for the cohousing movement. Training (of professionals) and education (schools teaching housing alternatives) were suggested as possibilities for 
countering the difficult processes involved in being a middle agent. In addition to the formal training initiatives offered in some countries, national and international cohousing networks (Textbox 1) can play a crucial role in the development and professional exchange of practical knowledge.

The USA in particular has a dominant culture of 'credentialism' (Collins, 1979). Certification of different kinds is issued there by established professionals for things like consensus decision-making - the most typical for these kinds of communities, Aging Successfully ${ }^{10}$. An intermediary organisation ${ }^{11}$, for instance, issues a certification framework that connects groups to certified professionals. Other individual professionals who cater to the co-housing sector advertise online as having certification in relevant specialist areas such as: Experiential Education/Group Leadership, Non-profit Management, Fundraising, Affordable Housing Feasibility, Project Management, and other professional specialties; others are 'Certified Passive House Consultant, LEED AP and Certified Green Professionals. But for some new professionals specialising in co-housing, like the social facilitator, such boundarysetting institutes or licences do not yet exist, although we found they are emerging particularly in the USA.

Such formal qualifications can also be at odds, or in tension with the more informal, lived experience that gives value to emerging professionals. Mainly, to be 'professional' implies a certain amount of disciplining (Schmidt 2000). But caught as they are between niche and mainstream, institutional and informal- encouraging the 'professionalism' of co-housing's middle agents through the setting of boundaries of knowledge and expertise does present a paradox ${ }^{12}$. A strict setting of parameters of knowledge and practice is in many ways antithetical to the values of co-housing as a DIY system of bottom-up, non-hierarchical self-management that values resident 'non-expert' knowledge. In this context, training and certification can be understood as both a necessity and a threat. On the one hand, having the correct knowledge in place means consultants can offer the skills and technical expertise needed from beginning to end, and be paid fairly for it. On the other, a closing off of what constitutes 'knowledge' through a credentialed system may deter passionate individuals like ex-residents from pursuing more informal avenues of knowledge sharing and professional expertise. 


\section{Conclusions}

In the countries we researched, where co-housing is still niche, being or becoming a co-housing professional means acting as 'a middle agent' able to successfully inhabit, travel across and coexist in the different worlds of mainstream and alternative housing expertise. Our discussion about co-housing's emerging forms of professional expertise frames these middle agents as key transmitters of knowledge and practice that mediate individual co-housing groups' as well as the wider movement's legitimacy and expansion.

This positioning between the mainstream and 'community-led' contexts allows them to communicate and negotiate between different stakeholder. The professional challenge lies primarily in guiding the group through critical steps, knowing how to articulate what's right from the group to the public and private sector and when it is right, for instance, to get a local councillor to endorse a project. The intimate relationship consultants often have across the co-housing spectrum with groups and other actors means they are in a privileged position of influence that can enable, expand or limit the possibilities of co-housing as a radical option or solution to the current mainstream offer. The presence of these 'socially skilled actors' has been key to the shape co-housing takes in particular individual cases and to their success, but their input over time also contributes to larger national trends in the sector. As such, their existence is central to the way this niche sector is defined and moves forward.

This positioning is also a continuous source of tension for this alternative, nonmainstream sector. Yet, as noted by our interviewees, there is no reason for informal systems of knowledge exchange and personal expertise not to coexist with a more formal cadre of co-housing specific professionals. The two are not mutually exclusive. What is needed are institutional support systems, to enable freelance individuals who already have to deal with their own economic uncertainty and that of working with groups, to pursue such opportunities, should they wish to do so. The roles, trajectories and insights discussed in this article reveals that their investment as professionals, even if this is a principal source of income, is not always self-interested but embedded in a broader ethics of cooperation or in an interest in moving the sector as a whole forward. Without an appropriate financial and network support system, 
their efforts can be short-lived and their ability to push the boundaries of the mainstream curtailed.

As such, we recommend that the training and capacity-building of middle-agents as a crucial, if paradoxical arena, receives further support. Professional accreditation and training that keeps individuals up to date and ensures they are giving the right advice is especially important, as development processes, legal and financial structures are ever-changing. However, the expressed need for 'quality control' through certification could also be framed as a kind of gate-keeping in an emerging professional sector, contrary to many of the working mechanisms and maxims of co-housing as a 'bottomup' democratic process, and product. We also argue that, given the unique 'middle agent' position of some co-housing professionals who trade in their personal experiences, training in this sector should not seek objectivity as an absolute ethical imperative. Instead the language of partiality and closeness should be incorporated to create its own sector-specific validity.

As the emerging titles of professionals demonstrate, and the building coach role in particular highlights, co-housing crosses over a range of different professional sectors. Technical, financial, legal and social skills are all (variously) required. This means that there are a number of vocational education paths it needs to be integrated into. It also means that in order to prepare students for these expanding non-traditional roles, educational curriculums need to understand the particularities of the 'middle out' position many of these consultants will end up performing. Finally, the non-traditional requests and processes the co-housing model implies may impact the jurisdictions and roles of traditional development partners, like Housing Associations, involved in the project. This could benefit general housing provision by offering new ways of addressing issues of affordability, sustainability or accessibility.

\section{Acknowledgements}

Firstly, the authors would like to thank all interviewees who generously gave their time and insights across all case-study countries. We are indebted to a large network of housing collaborators - both activists and academics- and in particular, to the Collaborative Housing Working Group of the European Network of Housing Researchers who read, commented and helped improve earlier versions of this work 
presentations in meetings in Northern Ireland and Delft. We are grateful also for the support received from Innovate UK; - without which the comparative angle of this research could not have been possible. And finally, a thank you to the anonymous reviewers who helped us develop and strengthen this piece. 


\section{REFERENCES}

Altmann, E. ( 2015 ) Industry professionalisation of strata title managers: what are the implications for governance? Property Management, 33(2), pp.187 - 204.

Altmann, E. (2016) Small scale housing unit developments: Implications for strata manager market penetration. Property Management, (34)3, pp.262-275.

Andresen, M. and Runge, U. (2002) Co-housing for seniors experienced as an occupational generative environment. Scandinavian Journal of Occupational Therapy, 9, pp. 156-166.

Bajracharya, B. and Khan, S. (2010) Evolving governance model for community building: collaborative partnerships in master planned communities, Urban Policy and Research, 28(4), pp. 471-485.

BIEB Available at: http://bouwenineigenbeheer.nl/

Blandy, S. and Lister, D. (2006), Gated communities: (Ne) gating community development?, in Atkinson, R. and Blandy, S. (Eds), Gated Communities, 1st ed., Routledge, Taylor \& Francis Group Ltd, Oxton, pp. 97-112.

Boyer, R. (2014). Sociotechnical Transitions and Urban Planning: A Case Study of Eco-Cohousing in Tompkins County, New York. Journal of Planning Education and Research, 34(4), pp. 451.

Boyer, R. and Leland, S. (2018) Cohousing For Whom? Survey Evidence to Support the Diffusion of Socially and Spatially Integrated Housing in the United States, Housing Policy Debate, 28(5), pp. 653-667

Brenton, M. (2013) Senior cohousing communities - an alternative approach for the UK? (JRF Programme Paper: A Better Life). London: Joseph Rowntree Foundation.

Bresson, S. and Tummers, L (2014) L'habitat participatif autogéré en Europe: vers des politiques alternatives de production de logements? Metropoles Politiques alternatives de développement urbain, 15. Available at: http://metropoles.revues.org/4622.

British Social Housing Foundation (now World Habitat) Available at: https://www.bshf.org/our-programmes/community-led-housing/

Krokfors, K. (2012) Editorial for special issue on "Co-Housing in the Making". Built Environment, 38(3), pp. 309-314.

Central Bureau of Statistics [CBS] (2012) Available at: $\mathrm{http}: / /$ statline.cbs.nl/Statweb/publication/?DM=SLNL\&PA=83706ned\&D1=a\& $\mathrm{D} 2=3 \& \mathrm{D} 3=0-2 \& \mathrm{D} 4=28-39 \& \mathrm{VW}=\mathrm{T}$

Chan, S. and Ellen, I.G. (2016) Housing for an Aging Population. Housing Policy 
Debate, 27 (2), pp. 167-192.

Choi, J. S. (2004). Evaluation of community planning and life of senior cohousing projects in Northern European countries. European Planning Studies, 12, pp. 11891216.

Cohousing Company (2017) Aging Successfully, Online Facilitator Training. Available at: http://www.cohousingco.com/events/2017/9/15/aging-successfullystudy-group-1-online-facilitator-training

Collins, R. (1979) The Credential Society: An Historical Sociology of Education and Stratification. New York: Academic Press.

Czischke, D. (2018) Collaborative housing and housing providers: towards an analytical framework of multi-stakeholder collaboration in housing coproduction. International Journal of Housing Policy, 18(1), pp. 55-81.

De Regie. Available at: http://www.deregie.nl/

Durrett, C. (2009) The Senior Cohousing Handbook: A community approach to independent living. Gabriola Island, Canada: New Society Publishers.

Dutch Cohousing and Senior CohousingAssociations Available at: http://www.lvgo.nl

Evetts, J. (2003) The sociological analysis of professionalism: Occupational change in the modern world. International Sociology, 18(2), pp. 395-415.

Evetts, J. (2011) A new professionalism? Challenges and opportunities. Current Sociology, 59(4), pp. 406-422.

Fainstein, S.S. (1993) The City Builders: Property, Politics and Planning in London and New York. Oxford, Blackwell.

Fernández Arrigoitia, M. and Scanlon, K. (2018) Of Flux or Finality? On the process and dynamics of a cohousing group-in-formation. In Benson, M. and Hamiduddin, I. (eds.). Self-Build Homes: social discourse, experiences and directions. London: UCL Press.

Fernández Arrigoitia, M., West, K. and Scanlon, K. (2018) Well-being and age in cohousing life: Thinking with and beyond design, Viewpoint 89, Housing Learning and Improvement Network, January.

Fernández Arrigoitia, M. and Scanlon, K. (2015). Co-designing senior co-housing: the collaborative process of Featherstone Lodge. Urban Design, 136, pp. 31-32

Garciano, J. L. (2011) Affordable Cohousing: Challenges and Opportunities for Supportive Relational Networks in Mixed-Income Housing. Journal of Affordable Housing \& Community Development Law, 20(2), pp. 169-92. 
Glass, A. P. (2012). Elder co-housing in the United States: Three case studies. Built Environment, 38(3), pp. 345-363.

Gutzon Larsen, H. (2019) Three phases of Danish cohousing: tenure and the development of an alternative housing form, Housing Studies.

Hickman, P., Pattison, B and Preece, J. (2018) The impact of welfare reforms on housing associations: a scoping study. Project Report. UK Collaborative Centre for

Holden, M. (2008) Social Learning in Planning: Seattle's Sustainable Development Codebooks. Progress in Planning, 69 (1), pp. 1-40

Hughes, W. and Hughes, C. (2013) Professionalism and professional institutions in times of change. Building Research \& Information, 41(1), pp. 28-38.

Fromm, D. (ed.) (2000) Special Themed Issue: Cohousing. Journal of Architectural and Planning Research, 17(2), pp.

Janda, K.B. and Parag, Y. (2013) A middle-out approach for improving energy performance in buildings. Building Research \& Information, 41 (1), pp. 39-50.

Jarvis, H. (2015) Toward a deeper understanding of the social architecture of cohousing evidence from the UK, USA and Australia. Urban Research and Practice 8(1), pp. 93-105.

Jarvis, H., Fernández Arrigoitia, M. and Scanlon, K. (2016) Cohousing: Shared Futures. London: Economic Social Research Council. Available at:

http://www.lse.ac.uk/geographyAndEnvironment/research/london/docs/Cohousi ng-shared-futures-FINAL-web.pdf

Kirby, A. (2003) Redefining social and environmental relations at the ecovillage at Ithaca: A case study. Journal of Environmental Psychology, 23, 323-332.

Krokfors, K. (2012) Editorial for special issue on 'Co-Housing in the Making'. Built Environment. 38 (3), pp. 309-314.

Labit, A. (2015) Self-managed co-housing in the context of an ageing population in Europe. Urban Research \& Practice, 8(1), pp. 32-45.

LaFond, M. and Tsvetkova, L. (2017) Cohousing Inclusive: Self-organised, Community-led Housing for All. Jovis.

Lang, R. and Stoeger, H. (2018) The role of the local institutional context in understanding collaborative housing models: empirical evidence from Austria. International Journal of Housing Policy, 18(1), pp. 35-54,

McCamant, K. and Durrett, C. (2011) Creating Cohousing. British Columbia: New Society Publishers. 
Moore, T. and McKee, K. (2012). Empowering Local Communities? An International Review of Community Land Trusts. Housing Studies, 27(2), pp.280-290.

Mullins, D. and Moore, T. (2018) Self-organised and civil society participation in housing provision. International Journal of Housing Policy, 18(1), pp. 1-14.

Qu, L. and Hasselaar, E. (eds.) (2011) Making Room for People: Choice, Voice and Liveability in residential places. Amsterdam: Techne Press.

Robinson, J. (2014) Introduction to a Virtual Issue on Comparative Urbanism. International Journal of Urban and Regional Research. Available at: https://www.ijurr.org/virtual-issues/comparative-urbanism/

Ruiu, M.L. (2017) Participatory processes in designing cohousing communities: the case of the community project. Housing and Society, 43(3), pp. 168-181.

Sanguinetti, A. (2014) Transformational practices in cohousing: Enhancing residents' connection to community and nature. Journal of Environmental Psychology, 40, pp. 86-96.

Sassen, S. (1992) The Global City. Princeton, NJ, Princeton University Press.

Scanlon, K. and Fernández Arrigoitia, M. (2015) Development of new cohousing: lessons from a London scheme for the over-50s. Urban Research \& Practice, 8 (1), pp. 106-121.

Stevenson, F., Barborska-Narozny, M. and Chatterton, P. (2016) Resilience, redundancy and low-carbon living: co-producing individual and community learning. Building Research and Information, 44 (7), pp. 789-803.

Sullivan, E. (2016) (Un)Intentional Community: Power and Expert Knowledge in a Sustainable Lifestyle Community. Sociological Inquiry, 86(4), pp. 540-562.

Cohousing Association of the United States. Available at: http://www.cohousing.org/

Tummers, L. (ed.) (2015a). Introduction to the Special Issue 'Taking Apart CoHousing. Towards a Long-term Perspective for Collaborative Self-Managed Housing in Europe'. Urban Research and Practice, 8 (1).

Tummers, L. (2015b) Self-Managed Co-Housing in the Netherlands: From 'Alternative Community' to 'I (Build My) -House'. In Wohbnd, e.V. (Ed.), Europe: Cooperative Housing/EUROPA: Gemeinsam Wohnen. Berlin: Jovis.

Williams, J. (2005) Designing neighborhoods for social interaction: The case of cohousing. Journal of Urban Design, 10 (2), pp. 19-227.

Wohnbund e. V. (ed.). (2015) Europa Gemeinsam wohnen|Europe Co-operative Housing. Berlin: Jovis. 

Table 1. Professional title/role of interviewees

\begin{tabular}{|c|c|c|}
\hline $\begin{array}{l}\text { Netherlands } \\
\text { (Amsterdam, Delft, Eindhoven, } \\
\text { Zutphen and Rotterdam) }\end{array}$ & $\begin{array}{l}\text { United States } \\
\text { (California, Massachusetts, } \\
\text { Washington, D.C.) }\end{array}$ & $\begin{array}{l}\text { UK } \\
\text { (London, Birmingham, York and } \\
\text { Newcastle upon Tyne) }\end{array}$ \\
\hline $\begin{array}{l}\text { N1-Engineering/technical } \\
\text { consultant } \\
\text { Cohousing expert and resident } \\
\text { Urban studies academic }\end{array}$ & $\begin{array}{l}\text { US1-Certified cohousing facilitator } \\
\text { Development consultant } \\
\text { Cohousing resident } \\
\text { Member of national cohousing } \\
\text { network } \\
\text { Cohousing author and blogger }\end{array}$ & $\begin{array}{l}\text { UK1- Specialist in housing and social } \\
\text { entrepreneurship } \\
\text { Homelessness expert } \\
\text { Board member of a care and support } \\
\text { charity, and of a social purpose housing } \\
\text { association group }\end{array}$ \\
\hline $\begin{array}{l}\text { N2-Self-build project manager } \\
\text { Procedural consultant } \\
\text { CPO resident }\end{array}$ & $\begin{array}{l}\text { US2- Architect } \\
\text { Founder and partner of architectural } \\
\text { firm with cohousing specialism. } \\
\text { Founding board member of the } \\
\text { Cohousing Network } \\
\text { Cohousing resident }\end{array}$ & $\begin{array}{l}\text { UK2- Project manager } \\
\text { Founder and partner of development and } \\
\text { regeneration firm with specialism in } \\
\text { cohousing }\end{array}$ \\
\hline $\begin{array}{l}\text { N3-Architect } \\
\text { DIY expert and developer }\end{array}$ & $\begin{array}{l}\text { US3-Architect } \\
\text { Founder and partner of architectural } \\
\text { firm with cohousing specialism. } \\
\text { Cohousing resident }\end{array}$ & $\begin{array}{l}\text { UK3- Cohousing network director } \\
\text { Cohousing network manager } \\
\text { Advisor and advocate of community } \\
\text { housing models }\end{array}$ \\
\hline $\begin{array}{l}\text { N4- Cohousing resident } \\
\text { Cohousing Network Board } \\
\text { member }\end{array}$ & $\begin{array}{l}\text { US4- Cohousing architect, developer } \\
\text { and resident } \\
\text { Cohousing Network Board member } \\
\text { Cohousing author }\end{array}$ & $\begin{array}{l}\text { UK4- Cohousing specialist and group } \\
\text { facilitator } \\
\text { Cohousing Network board member } \\
\text { Cohousing author }\end{array}$ \\
\hline $\begin{array}{l}\text { N5- } \\
\text { Self-build project manager } \\
\text { Procedural consultant } \\
\text { CPO resident and specialist }\end{array}$ & & $\begin{array}{l}\text { UK5- Housing development and } \\
\text { planning adviser } \\
\text { Cohousing Network board member }\end{array}$ \\
\hline $\begin{array}{l}\text { N6-Architect } \\
\text { Cohousing network board } \\
\text { member } \\
\text { Cohousing group founder and } \\
\text { resident }\end{array}$ & & \\
\hline
\end{tabular}


N7- Social facilitator

Governing board member of both cohousing networks

Sociologist/academic

Cohousing resident 
Table 2: Type of professions linked to co-housing production

\begin{tabular}{|c|c|c|c|c|}
\hline Professional title & Role/Description/jurisdiction & NL & $\mathbf{U S}$ & UK \\
\hline $\begin{array}{l}\text { Architects (including } \\
\text { eco-specialists, and } \\
\text { sustainability } \\
\text { experts) }\end{array}$ & $\begin{array}{l}\text { Commissioned by the housing association, } \\
\text { developer or the group itself to design homes with } \\
\text { common areas; they sometimes also act as group } \\
\text { and process facilitators, or 'building coach'. }\end{array}$ & $\mathrm{X}$ & $\mathrm{X}$ & $\mathrm{X}$ \\
\hline Engineers & $\begin{array}{l}\text { Technical advise on building structures and utilities } \\
\text { and, as such, important influencers for the } \\
\text { sustainability approach. Usually hired via } \\
\text { architects' networks. }\end{array}$ & & & \\
\hline Legal specialist & Advises on legal aspects or regulatory constraints & $\mathrm{X}$ & $\mathrm{X}$ & $\mathrm{X}$ \\
\hline Contractor & $\begin{array}{l}\text { Carries out (or subcontracts) all aspects related to } \\
\text { the construction/ build/ refurbishment }\end{array}$ & $\mathrm{X}$ & $\mathrm{X}$ & $\mathrm{X}$ \\
\hline $\begin{array}{l}\text { Developers } \\
\text { Investors }\end{array}$ & $\begin{array}{l}\text { Can be a housing association, individual or group. } \\
\text { If not the group, then developer negotiates with the } \\
\text { group's wishes and delivers the scheme. }\end{array}$ & $\mathrm{X}$ & $\mathrm{X}$ & $\mathrm{X}$ \\
\hline $\begin{array}{l}\text { Development or } \\
\text { procedural } \\
\text { consultant/ } \\
\text { 'Building coach' }\end{array}$ & $\begin{array}{l}\text { A type of management professional who guides a } \\
\text { group through decision-making and 'translates' the } \\
\text { technocratic planning vocabulary. }\end{array}$ & $\mathrm{X}$ & $\mathrm{X}$ & $\mathrm{X}$ \\
\hline $\begin{array}{l}\text { Social or cooperative } \\
\text { process consultant/ } \\
\text { Group or process } \\
\text { facilitator / Group } \\
\text { dynamic } \\
\text { expert/Project } \\
\text { enabler }\end{array}$ & $\begin{array}{l}\text { Provides personal and group consultations and } \\
\text { assistance; offers perspective, knowledge, advice, } \\
\text { as well as tools, tours, trainings, and referrals. }\end{array}$ & $\mathrm{X}$ & $\mathrm{X}$ & $\mathrm{X}$ \\
\hline Outreach volunteer & $\begin{array}{l}\text { Outreach education for would-be residents and } \\
\text { other interested stakeholders }\end{array}$ & & $\mathrm{X}$ & \\
\hline Marketing consultant & $\begin{array}{l}\text { Educating and informing people about co-housing } \\
\text { opportunities; setting up short or long-term } \\
\text { marketing programme for community. }\end{array}$ & & $\mathrm{X}$ & \\
\hline Policy advisors & For local authorities & $\mathrm{X}$ & & \\
\hline
\end{tabular}

\footnotetext{
${ }^{1}$ Some of the professional input that does exist is discussed, in that same collection, in terms of institutional housing providers (e.g., Housing Associations in Vienna and Lyon, see Czischke, 2018) and other strategic stakeholders (e.g., cooperatives and local authorities in Vienna and Salzburg, see Lang and Stoeger, 2018).

${ }^{2}$ It is based on research which was first presented at the 2016 ENHR Conference in Belfast and 2016 Seminar for the ENHR Working Group on Collaborative Housing in Delft.

${ }^{3}$ A project for Co-Ho North, via Innovate UK.

${ }^{4}$ While we point out some of the policy or urban planning drivers influencing professional trajectories, it is beyond the scope of this article to fully introduce the mainstream housing systems of countries.

${ }^{5}$ See: $\underline{\text { https://opendata.cbs.nl/\#/CBS/nl/dataset/82900NED/table?ts }=1560804639660}$

${ }^{6}$ Developments are more typically low-rise detached houses or attached dwellings with centralised communal facilities and peripheral parking- though design trends towards condominiums and more retrofit are shifting in recent years.

${ }^{7}$ See: http://cohousing.org.uk/cohousing-uk and http://cohousing.org.uk/groups
} 
${ }^{8}$ For discussions on inclusivity and affordability in the European context, see Droste, 2015; Garciano, 2011; Gutzon Larse, 2018; LaFond and Tsvetkova, 2017.

${ }^{9}$ E.g., BIEB [https://bouwenineigenbeheer.nl/] and De Regie [https://www.deregie.nl/].

${ }^{10}$ The US Cohousing Company hosts training for online facilitation on 'Aging Successfully'

(https://sagecohoadvocates.org/events/2018/10/10/study-group-1-aging-successfully-online-facilitatortraining) and the UK's workers co-op Seeds for Change offers training in: working non-hierarchically, consensus decision making, meeting facilitation skills and inclusive groups

(https://www.seedsforchange.org.uk/training).

${ }^{11}$ See: http://www.sagecohousingadvocates.org/about-us/

${ }^{12}$ We utilise the word paradox here to highlight a condition of apparent opposites, rather than a problem requiring normative solutions. Our contention is that if co-housing is to remain a force that works within but against the traditional mainstream way of producing homes, then the inevitable tensions inherent to the paradox must be recognised and negotiated as a productive reality. 